\title{
A Living Museum of Ceylon Trees
}

Dr G.M. Oza's article, 'Towards a "Living Museum" of Trees Typical of India' (Environmental Conservation, 13(2), pp. 173-4, 1986) brings to mind a somewhat similar but much more modest enterprise in Sri Lanka (formerly Ceylon).

Mr F.H. ('Sam') Popham, resident and self-styled 'Hermit' of Dambulla, in central Sri Lanka, has, since his retirement from the Smithsonian Ceylon Flora project, lived in his 'Cottage' on 28 hectares of formerly waste scrubland near Dambulla. A former tea-planter, but always interested in trees and fine woods, Popham undertook to plant and nurse to establishment, in this poor, unencouraging habitat, as many as he could get of the wealth of tree species that are native or immigrant in Sri Lanka. He soon found that spontaneous seedlings, released by his opening up of the dense thorn-scrub, grew much more successfully than those which were brought in from nurseries and other sources. Encouraged and guided by this success, Popham gradually developed an area with a dominance of the trees belonging to the Sri Lankan 'Semi-Evergreen Monsoon Dry Forest' that formerly covered a large proportion of the drier lowlands of the island.

Now, after 20 years of patient, gradual encouragement, a good representation of the tree flora of this formerly widespread dry tropical forest type has been developed, many of the species being already mature enough to be flowering and fruiting. Some of them are reproducing so actively that they have to be thinned out to avoid overcrowding and consequent stunting.

With care and protection from the prevalent destructive custom of slashing and burning ('chena') shifting cultivation, the soil deterioration is reversed, and the habitat improved, so that more and more species can find favourable conditions for establishment and growth. The result is a 28-hectares' 'island' of newly-restored 'jungle' representing the indigenous dry forest but existing in a vast expanse of degraded, overexploited land. Whether this will, by its example, influence any improvement in local land-use (or land-abuse) is as yet questionable. However, it undoubtedly could serve as a seed-source to reintroduce these fine forest trees to any similar areas whose owners find forest useful or desirable. Timber and firewood have become scarce and much-needed in those heavily-populated drier areas of the island.

Popham has published two short articles describing his project in the International Dendrology Society, London, Yearbooks for 1981 and 1985, with another almost ready for publication. The first of these contains a list of 44 tree species that had already been identified on the property, with their botanical, Sinhalese, and, where available, English vernacular, names.

This has been a strictly one-man effort, motivated only by a love of trees. It could serve as an example worthy of emulation practically everywhere except in the Arctic, Antarctic, and extreme desert, land areas of our Earth.

F. RAYMOND FOSBERG, Botanist Emeritus
National Museum of Natural History
Smithsonian Institution
Washington
DC 20560, USA.

\section{International Tropical Timber Agreement}

Prospects for conservation of tropical forests took a stride forward recently with the successful resolution of a lengthy dispute which had prevented the International Tropical Timber Agreement (ITTA) from coming into operation. The $41^{*}$ producer and consumer countries that are party to the ITTA - an international trade agreement with unique conservation clauses-resolved their dispute on where to locate the headquarters and who to appoint as Executive Director. The International Tropical Timber Organization (ITTO), which administers the Agreement, will now be operating from offices in Yokohama, Japan, with $\mathrm{Dr} \mathrm{H}$. 'Freddie' Freezaillah, of Malaysia, as Executive Director.

The breaking of the stalemate was greeted with relief by conservation groups such as WWF, which estimated that over 12 million ha of forest (an area larger than Austria) had been destroyed since the delegates first began arguing about offices in June 1985.

Conservation groups do not want to lose the ITTA, as it is the only UNCTAD (United Nations Conference on Trade and Development) commodity agreement which has the conservation of an important living resource as an objective. Thus Objective 1 .h of the ITTA commits parties to "encourage the development of national policies aimed at sustainable utilization and conservation of tropical forests and their genetic resources, and at maintaining the ecological balance of the regions concerned.'

Countries that are party to ITTA control over $95 \%$ of all trade in tropical timbers and a similar proportion of the remaining tropical forests. Under the Agreement, voting is divided between consumers and producers. The producer vote is then split according to the main regions (Africa, Asia, and South America) and allocated in proportion not

\footnotetext{
* Including EEC: 'a party but not a country'.-Ed.
}

just to trade but to the forests held, thus giving "votes for conservation.' Environmentalists have seized on the ITTA as the only intergovernmental agreement that is aimed at tropical forest conservation.

Commitment from environment and timber-trade groups, both of which support ITTA, has often looked stronger than the commitment of governments. Although ITTA took more than ten years to negotiate, and was deposited for signature after discussions between 70 governments, only the intervention of the London-based International Institute for Environment and Development (IIED) finally secured the backing of enough governments to save it from lapsing in April 1985, its scheduled date of implementation.

Subsequently, conservationists were faced with the need to renew their lobbying efforts because consumers threatened to pull out of the Agreement if no headquarters or director were chosen. Decision came the morning after a reception for delegates, hosted by WWF International Vice-President Prince Sadruddin Aga Khan, at which WWF launched a package of conservation measures including US \$5 millions for environment projects under ITTA, an export levy to finance reforestation schemes, and the appointment of a forest ecologist to ITTO. Referring to the significance of ITTA, Ronald van der Giessen of IIED said: 'Logging only destroys about ten per cent of forests directly - but indirectly it creates around 75 per cent of all losses through collateral damage and constructing roads, which allow settlers and developers to move into tropical forests.'

Japan had lobbied extensively for Yokohama to house the headquarters of ITTO, as that city is developing as a centre for international trade and the country is the largest single importer of tropical timber, dominating the world 